- FINANSE I PRAWO FINANSOWE.

- Journal of Finance and Financial Law

Czerwiec/June 2017 • vol. 2(14): 79-99

http://dx.doi.org/10.18778/2391-6478.2.14.07

\title{
NARUSZENIE PRAW KONSUMENTA W REKLAMIE UStUG FINANSOWYCH
}

\author{
Jacek Śliwa \\ Wydział Prawa i Administracji \\ Uniwersytet Rzeszowski \\ Izabela Sadowska \\ Wydział Prawa i Administracji \\ Uniwersytet Rzeszowski
}

\section{Streszczenie}

Niniejsza publikacja dotyczy obowiązków informacyjnych, które ustawodawca narzuca kredytodawcom i pośrednikom kredytowym już na etapie reklamy kredytów konsumenckich. Obowiązki te, wynikające $z$ ustawy o kredycie konsumenckim, nie zawsze jednak są respektowane przez instytucje finansowe, świadczące tego typu usługi. Wnioski takie można wyciągnąć przede wszystkim z analizy ostatnich decyzji Prezesa UOKiK, który wskazał na liczne nieprawidłowości w tym zakresie. W niniejszym opracowaniu omówione zostaną obowiązków informacyjne w zakresie oferowania usług kredytowych zawarte w ustawie o kredycie konsumenckim.

Słowa kluczowe: konsument, kredyt konsumencki, reklama usług finansowych, Urząd Ochrony Konkurencji i Konsumentów, obowiązki informacyjne.

JEL Class: K22, E51. 


\section{WPROWADZENIE}

Niniejsza publikacja dotyczy obowiązków informacyjnych, które ustawodawca narzuca kredytodawcom i pośrednikom kredytowym już na etapie reklamy kredytów konsumenckich. Zagadnienie to jest istotne przede wszystkim z uwagi na jego powszechny charakter, co potwierdza Raport Kwartalny Biura Informacji Kredytowej z marca 2017 r., według którego w 2016 r. liczba kredytów konsumpcyjnych, a więc takich do której mają zastosowanie przepisy ustawy o kredycie konsumenckim [Ustawa z dnia 12 maja 2011 r. ...] $]^{1}$ wynosiła 7.162.000 sztuk [Raport kwartalny z marca 2017 r. ...] $]^{2}$. Ponadto niniejsza tematyka jest ważna ze względu na rolę, jaką informacja odgrywa $\mathrm{w}$ procesie podejmowania decyzji o związaniu się węzłem umowy o kredyt konsumencki w prawidłowym i świadomym kształtowaniu praw i obowiązków stron. Obowiązki te, wynikające $\mathrm{z}$ ustawy o kredycie konsumenckim, nie zawsze jednak są respektowane przez instytucje finansowe, świadczące tego typu usługi. Wnioski takie można wyciągnąć przede wszystkim z analizy decyzji Prezesa Urzędu Ochrony Konkurencji i Konsumentów ${ }^{3}$, który wskazał na liczne nieprawidłowości w tym zakresie [Decyzje Prezesa UOKiK Nr DDK 3/2016; DDK 4/2016; DDK 5/2016; DDK 6/2016; DDK 7/2016, www.uokik.gov.pl, dostęp: 13.04.2016.]. Celem niniejszej publikacji jest empiryczna analiza adresowanych do konsumentów reklam usług finansowych, ze szczególnym uwzględnieniem kredytu konsumenckiego, pod kątem analizy teleologicznej obowiązujących w tym zakresie przepisów i ich oddziaływania na potencjalnych adresatów.

Artykuł opiera się na analizie unormowań prawnych na szczeblu zarówno Unii Europejskiej jak i krajowym, orzecznictwa Sądu Najwyższego, Trybunału Konstytucyjnego, decyzji Prezesa UOKiK, wytycznych Rzecznika Finansowego zawartych w Kanonie Dobrych Praktyk Rynku Finansowego, a także literatury dotyczącej przedmiotowej problematyki w aspekcie prawnym, która ukazała się na przestrzeni kilku ostatnich lat.

Autorzy publikacji analizują problem realizacji wymagań ustawowych dotyczących reklam wybranych usług finansowych pod kątem spełnienia celu jaki przyświecał w tym zakresie samemu ustawodawcy. Analizowana jest również skuteczność proponowanych rozwiązań legislacyjnych pod kątem przyjętego celu, przy założeniu specyficznych cech adresata reklamy. Analiza tych hipotez oparta jest na empirycznych badaniach ofert wybranych instytucji finansowych.

\footnotetext{
${ }^{1}$ Dalej jako ustawa o kredycie konsumenckim.

${ }^{2}$ Raport oparty na danych przekazywanych przez instytucje finansowe gromadzone w bazie BIK ze stanem na dzień 31.12.2016 r. - s. 7 .

${ }^{3}$ Dalej jako UOKiK.
} 
Podobne uregulowania $\mathrm{w}$ zakresie reklamy usług finansowych znalazły się również w ustawie z dnia 10.01.2017 r. o kredycie hipotecznym oraz o nadzorze nad pośrednikami kredytu hipotecznego i agentami, która niebawem wejdzie w życie [Ustawa z dnia 23 marca 2017 r. ... ${ }^{4}$. Ustawa ta implementuje postanowienia dyrektywy 2008/48/WE [Dyrektywa Parlamentu Europejskiego i Rady 2008/48/WE z dnia 23 kwietnia 2008 r. ...] $]^{5}$ i dyrektywy 2014/17/UE [Dyrektywa Parlamentu Europejskiego i Rady 2014/17/UE z dnia 04.02.2014 r. ... $]^{6}$, dopasowując normy w zakresie reklamy do tożsamych uregulowań zawartych w ustawie o kredycie konsumenckim, w celu ujednolicenia struktury przepisów powyższych aktów [Uzasadnienie rządowego projektu ustawy o kredycie hipotecznym oraz o nadzorze nad pośrednikami kredytu hipotecznego i agentami...: 14]. Jednakże z uwagi na profil kredytów hipotecznych, a także dodatkowe obostrzenia przy ich zawieraniu wynikające $\mathrm{z}$ nowowprowadzanej ustawy, nie zostały one objęte szczegółową analizą w niniejszym artykule.

\section{ZAGADNIENIA PODSTAWOWE}

Implementując Dyrektywę 2008/48/WE do krajowego porządku prawnego ustawodawca uchwalił ustawę $\mathrm{z}$ dnia 12.05.2011 r. o kredycie konsumenckim. Zgodnie z art. 3 ust $1 \mathrm{ww}$. ustawy przez umowę o kredyt konsumencki rozumie się umowę o kredyt w wysokości nie większej niż $255.550 \mathrm{zl}$, albo równowartość tej kwoty w walucie innej niż waluta polska, której kredytodawca w zakresie swojej działalności udziela lub daje przyrzeczenie udzielenia konsumentowi ${ }^{7}$.

Rozpatrując definicję kredytu konsumenckiego należy mieć na uwadze, że ustawodawca wprowadził pięć podstawowych jego form, nie jest to jednak katalog zamknięty, o czym świadczy zwrot „w szczególności”. Do form tych należą umowa pożyczki, umowa kredytu w rozumieniu przepisów prawa bankowego, umowa o odroczenie konsumentowi terminu świadczenia pieniężnego, umowa o kredyt, w której kredytodawca zaciąga zobowiązanie wobec osoby trzeciej,

\footnotetext{
${ }^{4}$ Zgodnie $\mathrm{z}$ art. 94 tejże ustawy, poza wyjątkami, wchodzi ona w życie po upływie 3 miesięcy od dnia ogłoszenia. Ustawa została ogłoszona w dzienniku ustaw w dniu 21.04.2017 r., wchodzi więc w życie w dniu 22.07.2017 r.

${ }^{5}$ Dalej jako dyrektywa 2008/48/WE.

${ }^{6}$ Dalej jako dyrektywa 2014/17/UE.

${ }^{7}$ Limit wartości kredytu wyrażony w niniejszym artykule wynika z postanowienia art. 28 Dyrektywy 2008/48/WE i odpowiada on kwocie 75.000 euro przeliczonej po kursie wymiany w dniu przyjęcia dyrektywy tj. 23.04.2008 r.
} 
a konsument zobowiązuje się do zwrotu kredytodawcy spełnionego świadczenia oraz kredyt odnawialny ${ }^{8}$.

Przedmiotem niniejszego opracowania są zagadnienia dotyczące kredytu konsumenckiego, w związku z czym przy rozważaniach czy dana umowa do takowych się odnosi, należy mieć na uwadze art. 3 i art. 4 ustawy o kredycie konsumenckim, które wyznaczają zakres jej stosowania.

Ustawa o kredycie konsumenckim definiując pojęcie konsumenta odsyła do art. $22^{1}$ kodeksu cywilnego [Ustawa z dnia 23 kwietnia 1964 r. ...], według którego, jest to osoba fizyczna dokonująca z przedsiębiorcą czynności prawnej niezwiązanej bezpośrednio z jej działalnością gospodarczą lub zawodową.

Za jedno z głównych i podstawowych praw konsumenta należy uznać prawo do rzetelnej i pełnej informacji o produkcie. Obowiązek informacyjny ma na celu wyrównanie pozycji konsumenta i profesjonalisty, dlatego jego podwalin możemy doszukiwać się już w art. 76 Konstytucji Rzeczypospolitej Polskiej [Konstytucja Rzeczypospolitej Polskiej z dnia 02 kwietnia 1997 r. ...], który nakłada na władze publiczne obowiązek ochrony konsumentów między innymi przed nieuczciwymi praktykami handlowymi, a za takie niewątpliwie należy uznać niepełne i wprowadzające w błąd informacje przekazywane przez kredytodawców i pośredników kredytowych w reklamach usług finansowych [Rutkowska-Tomaszewska 2014c].

Ustawodawca w celu zabezpieczenia prawa konsumenta do informacji uregulował szczegółowe przepisy w tym zakresie m.in. w art. 8 i art. 12 ustawy o prawach konsumenta [Ustawa $\mathrm{z}$ dnia 30 maja 2014 r. ...] ${ }^{10}$, w art. 6 ust. 4 ustawy o przeciwdziałaniu nieuczciwym praktykom rynkowym [Ustawa z dnia 23 sierpnia 2007 r. ... $]^{11}$, ponadto sama ustawa o kredycie konsumenckim w art. 13 podaje zakres informacji jakie kredytodawca lub pośrednik kredytowy przed zawarciem umowy o kredyt konsumencki jest zobowiązany podać konsumentowi. Ponadto określa, iż informacje te muszą zostać udostępnione konsumentowi na trwałym nośniku ${ }^{12}$.

${ }^{8}$ Wymienione w tym miejscu formy kredytu konsumenckiego wynikają z art. 3 ust. 2 ustawy o kredycie konsumenckim. O definicji kredytu na gruncie regulacji kredytu konsumenckiego zobacz także: Tereszkiewicz [2014: 57-60].

${ }^{9}$ Art. 4 ustawy o kredycie konsumenckim określa sytuacje, w których nie mają zastosowania przepisy ustawy o kredycie konsumenckim.

${ }^{10} \mathrm{~W}$ wymienionych przepisach prawnych ustawodawca określił obowiązki informacyjne przedsiębiorców w umowach zawieranych na odległość lub poza lokalem przedsiębiorstwa (art. 12) oraz w umowach innych niż powyższe (art. 8).

${ }^{11} \mathrm{~W}$ wymienionym przepisie ustawodawca określił jakie informacje należy uznać za istotne w przypadku propozycji nabycia produktu.

${ }^{12}$ Art. 13 ustawy o kredycie konsumenckim. Por. także: Rutkowska-Tomaszewska [2014c: 139 i n.]. 
Jak wynika z orzecznictwa Sądu Najwyższego konsument ma prawo do kompletnej i jednoznacznej informacji w sprawach mających istotne znaczenie dla zabezpieczenia jego interesu prawnego w warunkach globalizacji (masowości) obrotu prawnego i wielości ofert na rynku, które nie zawsze posługują się prawdziwymi i pełnymi informacjami, a niekiedy wprowadzają w błąd lub w sposób ukryty godzą w indywidualny i zbiorowy interes konsumentów [Wyrok Sądu Najwyższego z dnia 20 czerwca 2006 r. ...].

Zagadnienie to jest na tyle istotne, że stało się także przedmiotem rozważań Trybunału Konstytucyjnego, który już kilkanaście lat temu stwierdził, że ochrona konsumenta przez dostarczenie mu niezbędnych informacji do podjęcia świadomej decyzji rynkowej jest strategicznym założeniem współczesnej ochrony konsumenta w ogólności [Wyrok Trybunału Konstytucyjnego z dnia 21 kwietnia 2004 r. ...].

W niniejszym opracowaniu omówione zostaną obowiązków informacyjne w zakresie oferowania usług kredytowych zawarte w ustawie o kredycie konsumenckim.

\section{OGÓLNE WARUNKI PREZENTOWANIA REKLAM USŁUG KREDYTOWYCH}

Na wstępie rozważań należy wyjaśnić, iż definicja reklamy zawarta została $\mathrm{w}$ art. 4 pkt 17 ustawy z 29.12.1992 r. o radiofonii i telewizji [Ustawa z dnia 29 grudnia 1992 r. .... $]^{13}$ - „reklamą jest przekaz handlowy, pochodzący od podmiotu publicznego lub prywatnego, w związku z jego działalnością gospodarczą lub zawodową, zmierzający do promocji sprzedaży lub odpłatnego korzystania $\mathrm{z}$ towarów lub usług; reklamą jest także autopromocja" ${ }^{14}$. Ponadto w doktrynie postulowany jest pogląd, iż z uwagi na cel dyrektywy 2008/48/WE ${ }^{15}$ pojęcie reklamy należy interpretować szeroko, a więc powinno ono obejmować obok reklamy także inne materiały o handlowym charakterze, w szczególności materiały wymienione w art. 71 kodeksu cywilnego [Chruściak i in. 2012, Komentarz

${ }^{13}$ Dalej ustawa o radiofonii i telewizji.

${ }^{14}$ Jak wskazuje Lesław Góral w polskim prawie nie ma jednolitej definicji reklamy. Znaleźć można wiele definicji legalnych mających znaczenie jedynie w zakresie stosowania danego aktu prawnego - zob. Góral [2012: 399]. Jednakże z uwagi na fakt, iż w zakresie reklamowania kredytów konsumenckich ustawodawca nie przewidział definicji legalnej reklamy, autorzy przyjęli definicję zawartą w ustawie o radiofonii i telewizji jako wiodącą w niniejszej pracy.

${ }^{15}$ Celem przepisów dyrektywy 2008/48/WE, a tym samym przepisów uchwalonych w konsekwencji implementacji tejże dyrektywy, jest ochrona konsumenta przed nieuczciwymi praktyki w zakresie reklamy kredytu konsumenckiego, a także dostarczenie im już na etapie reklamy kredytu pewnego standardowego zakresu informacji w celu umożliwiania porównana ofert różnych kredytodawców. 
do Art. 7. Teza 5]. Artykuł ten wymienia, obok reklamy, także ogłoszenia, cenniki i inne informacje, skierowane do ogółu lub do poszczególnych osób, jeśli oczywiście odnoszą się one do kredytu.

Analizując to zagadnienie należy pamiętać, że reklama wykonywana może być w sposób różnoraki, począwszy od reklamy prasowej, radiowej, telewizyjnej, pocztowej kończąc na internetowej. Jak wskazuje doktryna, jedną z podstawowych cech reklamy jest kierowanie przekazu, który zawiera informację powiązane z zachętą do skorzystania z oferowanych usług [Ofiarski 2015, Komentarz do Art. 7. Pkt 2. Istota i forma reklamy]. Należy pamiętać, iż podstawowym jej celem powinna być świadoma i racjonalna decyzja dotycząca wyboru oferty z uwzględnieniem rzeczywistych potrzeb konsumenta [Czech 2012, Komentarz do Art. 7. Teza 2]. Gdyby kredytodawcy oferujący usługi finansowe mieli to na uwadze, konsumenci posiadający szerokie spektrum informacji dokonywaliby, w oparciu o porównanie różnych ofert, świadomego wyboru. Posiadając odpowiednią wiedzę, byliby w stanie dokonać wyboru oferty najkorzystniejszej w danej sytuacji i czasie [Uzasadnienie projektu ustawy o kredycie konsumenckim...: 20, dostęp: 13.04.2016].

Odnosząc się do elementu prawidłowego prezentowania usług finansowych przedsiębiorcy powinni mieć na uwadze konieczność dostosowania formy reklamy do „specyfiki medium wykorzystywanego do jej rozpowszechniania"16.

Dodatkowe ogólne regulacje odnoszące się do zasad prezentowania ofert finansowych znajdują się w Międzynarodowym Kodeksie Etycznym Reklamy, który podkreśla, że nie powinno się używać tekstu i obrazu, które bezpośrednio lub przez aluzję, dwuznaczność lub przesadne stwierdzenia co do faktów rzeczywistych wprowadzają konsumenta w błąd [Rutkowska-Tomaszewska 2011: 87].

\section{ZAKRES PRZEDMIOTOWY OBOWIAZZKU INFORMACYJNEGO NA ETAPIE REKLAMY}

Zakres przedmiotowy obowiązku informacyjnego na etapie reklamy zawiera art. 7 ustawy o kredycie konsumenckim, który określa, iż kredytodawca lub pośrednik kredytowy są zobowiązani podać konsumentowi w reklamie kredytu konsumenckiego: stopę oprocentowania kredytu wraz $\mathrm{z}$ wyodrębnieniem opłat uwzględnianych w całkowitym koszcie kredytu, całkowitą kwotę kredytu, a także rzeczywistą roczną stopę oprocentowania. Ponadto w stosownych przy-

16 Ofiarski [2012, Komentarz do Art. 7. Pkt 2. Istota i forma reklamy] (...). Na powyższe zwróciła uwagę również Komisja Nadzoru Finansowego w piśmie z dnia 13 kwietnia 2012 r. nr DOK/WPR/0735/5/1/12/BK, w którym wskazała, iż wszelkie istotne elementy składające się na przekaz reklamowy w przypadku kredytu konsumenckiego powinny być dostosowane do specyfiki medium wykorzystywanego do jego rozpowszechniania. 
padkach, podają konsumentowi czas obowiązywania umowy, całkowitą kwotę do zapłaty przez konsumenta oraz wysokość rat, cenę towaru lub usługi oraz kwotę wszystkich zaliczek w przypadku umowy o kredyt przewidującej odroczenie płatności.

Stopa oprocentowania kredytu to zgodnie z art. 5 pkt 10 ustawy o kredycie konsumenckim: „stopa oprocentowania wyrażona jako stałe lub zmienne oprocentowanie stosowane do wypłaconej kwoty na podstawie umowy o kredyt w stosunku rocznym". Jak wynika więc z treści powyższego przepisu może ona przyjąć postać oprocentowania w formie stałej lub zmiennej. Ta pierwsza określa wartością procentową obowiązującą w całym czasie trwania umowy kredytu lub w pewnych jej okresach, natomiast druga może ulegać podwyższeniu lub obniżeniu w czasie trwania umowy kredytu w wyniku dostosowania jej do aktualnych warunków gospodarowania pieniądzem, warunków jego uzyskania i jego siły nabywczej [Ofiarski 2012, Komentarz do Art. 5. Teza 10. Stopa oprocentowania kredytu]. Precyzując pojęcie stopy oprocentowania należy wskazać, iż oznacza ona stawkę procentową, która służy do obliczenia odsetek od kredytu [Czech 2012, Komentarz do Art. 5. Teza 144]. Innymi słowy stopa procentowa to czynnik, który wraz z sumą kredytu kształtuje iloczyn należnej kredytodawcy kwoty odsetek, w określonym umownie przedziale czasu [Ofiarski 2012, Komentarz do Art. 5. Teza 10. Stopa oprocentowania kredytu]. Abstrahując od możliwości ingerowania każdej ze stron w wysokość stopy oprocentowania kredytu, gdyż w wielu przypadkach jest to uprawnienie przysługujące jedynie kredytodawcy, jednakże może się zdarzyć, iż również kredytobiorca będzie miał wpływ na kształtowanie jej wysokości, koniecznym jest wskazanie, iż w żadnym wypadku nie może ona przekroczyć wysokości odsetek maksymalnych, które zgodnie z obecnie obowiązującym art. $359 \S 2^{1}$ k.c. nie mogą w stosunku rocznym przekraczać dwukrotności wysokości odsetek ustawowych (odsetki maksymalne) ${ }^{17}$. Odnosząc powyższe do stopy oprocentowania kredytu należy stwierdzić, iż od 2016 r. nie może ona być wyższa niż 10\% w stosunku rocznym ${ }^{18}$.

Stopa oprocentowania jako element umowy kredytu został przez ustawodawcę uznany za istotny, w ujęciu obowiązku informacyjnego kredytodawcy, gdyż de facto jest elementem składowym świadczenia głównego stron umowy

${ }^{17}$ Zmiana $\mathrm{w}$ tym zakresie weszła w życie od 01.01 .2016 r. ustawą z dnia 09 października 2015 r. ... Jak natomiast wynika z Obwieszczenia Ministra Sprawiedliwości z dnia 07 stycznia 2016 r. w sprawie wysokości odsetek ustawowych, wydanego na podstawie art. $359 \S 4$ ustawy z dnia 23 kwietnia 1964 r. ... poczynając od dnia 01.01.2016 r. wysokość odsetek ustawowych wynosi $5 \%$ w stosunku rocznym.

${ }^{18}$ Zgodnie z art. 359 § 2 k.c. odsetki ustawowe są równe sumie stopy referencyjnej Narodowego Banku Polskiego i 3,5 punktów procentowych. Zgodnie natomiast z Obwieszczeniem Ministra Sprawiedliwości w sprawie wysokości odsetek ustawowych z dnia 07 stycznia 2016 r. ... poczynając od dnia 01.01.2016 r. wysokość odsetek ustawowych wynosi 5\% w stosunku rocznym. Tym samym odsetki maksymalne obecnie wynoszą 10\% w stosunku rocznym. 
kredytu. $\mathrm{Z}$ jednej bowiem strony jest to cena jaką płaci kredytobiorca w zamian za oddanie mu środków finansowych do dyspozycji, a z drugiej strony jest to wynagrodzenie dla kredytodawcy za ich udostępnienie [Ofiarski 2012, Komentarz do Art. 5. Teza 10. Stopa oprocentowania kredytu]. Dlatego też informacja ta już na etapie reklamy kredytu konsumenckiego powinna zostać podana w sposób jednoznaczny, zrozumiały i widoczny.

Wraz ze stopą oprocentowania kredytodawca zobowiązany jest w reklamie podać konsumentowi wyodrębnienie opłat uwzględnianych w całkowitym koszcie kredytu. Jak wynika to natomiast $\mathrm{z}$ art. 5 pkt 6 ustawy o kredycie konsumenckim „całkowity koszt kredytu to wszelkie koszty, które konsument jest zobowiązany ponieść w związku z umową o kredyt, w szczególności:

a) odsetki, opłaty, prowizje, podatki i marże jeżeli są znane kredytodawcy oraz

b) koszty usług dodatkowych w przypadku gdy ich poniesienie jest niezbędne do uzyskania kredytu

- z wyjątkiem kosztów opłat notarialnych ponoszonych przez konsumenta".

Jak wynika $z$ analizy tego przepisu, wykaz kosztów kredytu nie stanowi katalogu zamkniętego, ustawodawca wymienia jedynie te najbardziej typowe jakie występują w obrocie. W związku z powyższym, jeżeli w ofercie kredytu konsumenckiego pojawią się dodatkowe koszty obciążające konsumenta, kredytodawca jest zobowiązany do ich podania konsumentowi już na etapie reklamy. Do całkowitego kosztu kredytu należy zaliczyć koszty, do których poniesienia konsument zobowiązał się na podstawie umowy o kredyt, nie uzależniając tego obowiązku od powstania jakichkolwiek zdarzeń przyszłych czy warunków. Do całkowitego kosztu kredytu wlicza się również koszty usług dodatkowych w przypadku, gdy ich poniesienie jest niezbędne do uzyskania kredytu. Innymi słowy, zgodnie z przyjętym w doktrynie stanowiskiem, do całkowitych kosztów kredytu należą te koszty, do których poniesienia konsument będzie zobowiązany [Ofiarski 2012, Komentarz do Art. 5. Teza 6. Całkowity koszt kredytu].

Kolejnym elementem wymaganym do podania na etapie reklamy kredytu konsumenckiego jest całkowita kwota kredytu. Zgodnie z art. 5 pkt 7 ustawy o kredycie konsumenckim jest to „suma wszystkich środków pieniężnych, które kredytodawca udostępnia konsumentowi na podstawie umowy o kredyt". Tak przyjęta definicja tego pojęcia jest efektem implementacji art. 3 lit. 1 dyrektywy 2008/48/WE. Wyrażenie użyte przez ustawodawcę - „suma wszystkich środków pieniężnych, które kredytodawca udostępnia konsumentowi na podstawie umowy o kredyt" jest tożsame $\mathrm{z}$ określeniem użytym przez prawodawcę unijnego, według którego całkowita kwota kredytu oznacza „maksymalną kwotę lub łączne kwoty udostępnione na podstawie umowy o kredyt"19. Zgodnie ze stanowi-

${ }^{19}$ Art. 3 lit. 1 dyrektywy 2008/48/WE. 
skiem UOKiK pojęcie całkowitej kwoty kredytu oznacza inaczej kwotę jaką konsument będzie mógł dysponować w sposób dowolny po zawarciu umowy [Decyzja częściowa Prezesa UOKiK Delegatura w Bydgoszczy nr RBG - 10/2014 z dnia 22 maja 2014 r.]. Jednakże trudności może nastręczać konsumentowi fakt stosowania pojęć: całkowita kwota kredytu, całkowity koszt kredytu i całkowita kwota do zapłaty przez konsumenta. Rozumowanie, przez potencjalnego konsumenta, przy założeniu, że chociaż w minimalnym stopniu orientuje się w powyższej tematyce, pojęcia całkowitej kwoty do zapłaty jako sumy całkowitej kwoty kredytu i całkowitego kosztu kredytu, może bowiem prowadzić do wniosku, iż całkowita kwota kredytu to kwota rzeczywiście udzielana konsumentowi. Praktyka instytucji kredytowych w tym zakresie bywała jednak różna. Gdyż niekiedy zdarza się, iż kredytodawcy wliczając opłaty i prowizje w ciężar kredytu podawali konsumentom całkowitą kwotę kredytu jako kwotę do wypłaty połączoną z kwotą opłat i prowizji. W ocenie organu ochrony konsumentów przedsiębiorca wprowadza konsumentów w błąd, co do proporcji między całkowitym kosztem kredytu a całkowitą kwotą kredytu, w sytuacji w której prezentuje informacje o całkowitej kwocie kredytu obliczonej przy założeniu, że powinna ona uwzględniać kredytowane koszty kredytu ${ }^{20}$. Zdaniem UOKiK do całkowitej kwoty kredytu nie mogą zostać wliczone opłaty za udzielenie przedmiotowego kredytu, w tym opłaty, prowizje czy też odsetki, a wszystkie koszty związane z udzieleniem kredytu ponoszone przez konsumenta powinny zostać umieszczone jedynie w całkowitym koszcie kredytu [Pismo UOKiK z dnia 20 lutego 2012 r. nr DDK-076-118/11/BK...]. Podobne stanowisko w niniejszej kwestii zajęła Komisja Europejska w Wytycznych w sprawie stosowania przepisów dyrektywy o kredycie konsumenckim dotyczących rzeczywistej rocznej stopy oprocentowania [European Commission 2012: 11]. Również w doktrynie podkreśla się, iż w przypadku zaliczenia jakiś opłat czy prowizji w ciężar kredytu, wtedy na potrzeby wyliczenia całkowitej kwoty do zapłaty przez konsumenta (art. 5 pkt 8 ustawy o kredycie konsumenckim) - termin całkowitej kwoty kredytu ,nie obejmuje kapitału w zakresie, w jakim - stosownie do postanowień umowy - jest on przeznaczony wyłącznie na sfinansowanie odsetek, opłat, prowizji i innych kosztów (w tym kosztów usług

${ }^{20}$ UOKiK w piśmie z dnia 20 lutego 2012 r. nr DDK-076-118/11/BK kierowanym do Prezesa Związku Banków Polskich stwierdził, iż dla zabezpieczenia interesów konsumentów konieczne jest przyjęcie przez wszystkich kredytodawców jednolitej praktyki w zakresie informowania o całkowitej kwocie do zapłaty w przypadku kredytowania niektórych kosztów kredytu. W piśmie tym UOKiK słusznie wskazał, iż w przypadku gdy oferty dwóch kredytodawców nie różnią się od siebie, a pierwszy kredytodawca uwzględnia kredytowaną prowizję zarówno w całkowitej kwocie kredytu, jak i w całkowitym koszcie kredytu, a drugi kredytodawca uwzględnia taką prowizję jedynie w całkowitym koszcie kredytu, to w efekcie konsument uzyska wprowadzającą w błąd informację, że rzeczywista roczna stopa oprocentowania dla pierwszego kredytu jest niższa, niż rzeczywista roczna stopa oprocentowania dla drugiego kredytu. 
dodatkowych) ponoszonych przez konsumenta w związku z umową o kredyt konsumencki" [Czech 2012, Komentarz do Art. 5. Teza 124]. W przeciwnym razie koszty te uwzględniane byłyby dwukrotnie.

Istotną informacją, którą kredytodawca reklamujący swoje usługi związane z kredytem konsumenckim jest zobowiązany przekazać konsumentowi, jest rzeczywista roczna stopa oprocentowania ${ }^{21}$. Zgodnie z art. 5 pkt 12 ustawy o kredycie konsumenckim jest to całkowity koszt kredytu ponoszony przez konsumenta, wyrażony jako wartość procentowa całkowitej kwoty kredytu w stosunku rocznym. Podanie konsumentowi tej informacji ma głównie na celu umożliwienie obiektywnego porównania przez niego ofert kredytowych różnych kredytodawców. ${ }^{22}$ Obliczenie RRSO jest obowiązkiem kredytodawcy lub pośrednika kredytowego. Sposób jej obliczania określony został w załączniku nr 4 do ustawy o kredycie konsumenckim, w którym zostały określone także założenia jakie należy przyjąć przy jej obliczaniu. RRSO jest wyliczana indywidualnie dla każdego kredytu w zależności od jego wartości, daty udzielenia i czasu spłaty oraz kosztów kredytu ponoszonych przez kredytobiorcę. W praktyce uznaje się, iż RRSO jest podstawowym instrumentem umożliwiającym konsumentowi dokonanie obiektywnej decyzji zawarcia umowy o kredyt poprzez porównanie ofert instytucji finansowych. Jak wskazuje się jednak w doktrynie, należy pamiętać, iż nie jest to instrument doskonały, przede wszystkim z tego powodu, iż umowy o kredyt konsumencki mogą być stworzone w oparciu o różne warunki, zarówno co do okresu trwania umowy, zasady wpłat, zasad pobierania opłat i prowizji [Czech 2012, Komentarz do Art. 5. Teza 163]. RRSO natomiast ujmuje, te wszystkie warunki zróżnicowane w stosunku do każdej umowy, w postaci jednego parametru, który może prowadzić do nieracjonalnych wniosków, w szczególności w przypadku kredytów krótkoterminowych [Czech 2012, Komentarz do Art. 5. Teza 163].

Wszystkie trzy, opisane wyżej elementy wymagane do podania w przypadku reklamy kredytu konsumenckiego, zgodnie z art. 8 ust. 1 ustawy o kredycie konsumenckim „kredytodawca lub pośrednik kredytowy podaje na podstawie reprezentatywnego przykładu". Reprezentatywny przykład to inaczej przykład charakterystyczny (powszechny, typowy). Jedynie informacyjnie należy wskazać, iż przy określaniu reprezentatywnego przykładu należy określić warunki umowy o kredyt konsumencki, na których kredytodawca lub pośrednik kredytowy spodziewa się zawrzeć co najmniej dwie trzecie umów danego rodzaju przy uwzględnieniu przez te umowy średniego okresu kredytowania, całkowitej

${ }^{21}$ Dalej jako RRSO.

${ }^{22}$ Czech [2012, Komentarz do Art. 5. Teza 165]. (...). Ponadto jak wskazuje Edyta Rutkowska-Tomaszewska RRSO ma zapobiegać wprowadzaniu konsumentów w błąd co do faktycznych kosztów zaciąganego kredytu - por. Rutkowska-Tomaszewska [2014b: 139 i n.]. 
kwoty kredytu i częstotliwości występowania na rynku umów danego rodzaju ${ }^{23}$. Dodatkowo zarówno kredytodawca jak i pośrednik kredytowy są zobowiązani gromadzić odpowiednie dane $\mathrm{w}$ celu ustalenia na ich podstawie reprezentatywnego przykładu ${ }^{24}$.

W stosownych przypadkach kredytodawca bądź pośrednik kredytowy jest zobowiązany do podania konsumentowi okresu obowiązywania umowy, całkowitej kwoty do zapłaty przez konsumenta oraz wysokości rat i cenę towaru lub usługi oraz kwotę wszystkich zaliczek w przypadku umowy o kredyt przewidującej odroczenie płatności ${ }^{25}$. Jak wskazuje się w doktrynie informacje powyższe nie zamieszcza się w przypadku reklamy, która nie dotyczy kredytu konsumenckiego albo z różnych przyczyn nie są one znane kredytodawcy [Czech 2012, Komentarz do Art. 7. Teza 24]. Okres obowiązywania umowy oraz wysokość rat nie wymagają szczegółowych wyjaśnień, zaś co do pojęcia całkowitej kwoty do zapłaty przez konsumenta, została ono wyjaśnione powyżej, a przypominająco jedynie można wskazać, że stanowi ona sumę całkowitego kosztu kredytu i całkowitej kwoty kredytu. Jedynie porządkująco w tym miejscu należy wyjaśnić, iż umowa o kredyt przewidująca odroczenie płatności polega na tym, iż strony umowy ustalają nowy, bardziej odległy termin spełnienia świadczenia [Ofiarski 2012, Komentarz do Art. 3. Teza 2.3. Umowa o odroczeniu konsumentowi terminu spełnienia świadczenia pieniężnego]. W przeważającej ilości przypadków takie odroczenie płatności wiąże się z zapłatą dodatkowej prowizji, w związku z czym w tym zakresie ustawodawca przewidział konieczność już na etapie reklamy do informowania potencjalnego kredytobiorcy o kosztach związanych $\mathrm{z}$ taką umową.

Wskazać w tym miejscu należy również, iż część doktryny stoi na stanowisku, iż w przypadku, gdy reklama kredytu konsumenckiego ogranicza się do ogólnych sformułowań dotyczących kosztów kredytu np. „korzystne oprocentowanie”, ,najniższy kredyt na rynku” to nie podlega ona przepisowi art. 7 ust. 1 ustawy o kredyt konsumencki. Reżimowi zawartemu w tym przepisie będzie podlegać natomiast reklama, w której dane liczbowe wyrażono w sposób negatywny np. „kredyt zero procent” ${ }^{\text {26 }}$. Z powyższym jednak nie można się zgodzić. Art. 7 ustawy o kredycie konsumenckim wyraźnie nakłada obowiązek informacyjny na kredytodawców lub pośredników kredytowych w przypadku reklam zawierających dane dotyczące kosztu kredytu konsumenckiego. Niezgodne z celem ustawy o kredycie konsumenckim, a w konsekwencji także i dyrektywy 2008/48/WE byłoby gdyby reklamy kredytów konsumenckich, które mimo

${ }^{23}$ Powyższe wynika $\mathrm{z}$ art. 8 ust. 2 ustawy o kredycie konsumenckim.

${ }^{24}$ Powyższe wynika $\mathrm{z}$ art. 8 ust. 3 ustawy o kredycie konsumenckim.

${ }^{25}$ Powyższe wynika $z$ art. 7 ust. 2 ustawy o kredycie konsumenckim.

${ }^{26}$ Tak Kopeć-Kowalczyk [2014: 105-125]. Por. także: Rutkowska-Tomaszewska [2014a: 139 i n.]. 
ogólnych stwierdzeń, w pewien sposób i tak dotykają zagadnienia kosztów kredytu, wyłączyć z zakresu regulacji art. 7 ustawy o kredycie konsumenckim.

$Z$ powyższej analizy wynika, iż ustawodawca celem zabezpieczenia interesu konsumenta zobowiązuje kredytodawców bądź pośredników kredytowych do dość szczegółowego określenia warunków umowy o kredyt konsumencki. Po wstępnej analizie tych zagadnień można stwierdzić, iż obowiązek informacyjny w wyżej wskazanym zakresie jest słuszny i pozwala konsumentowi na realne i obiektywne porównanie ofert kredytowych. Pojawia się jednak pytanie czy zakres tych informacji oraz stopień ich skomplikowania rzeczywiście daje konsumentowi możliwość porównywania ofert kredytowych. Ujawnia się tutaj kwestia modelu konsumenta jaki przyjmuje każdy $\mathrm{z}$ ustawodawców unijnych ${ }^{27}$. Zagadnienie to nie stanowi problematyki niniejszego artykułu. Warto jednak zastanowić się nad tym, czy potencjalny konsument w Polsce jest na tyle biegły w zakresie kredytu konsumenckiego, iż wie co oznaczają pojęcia całkowitego kosztu kredytu, całkowitej kwoty kredytu, stopy oprocentowania, rzeczywistej rocznej stopy oprocentowania, całkowitej kwoty do zapłaty przez konsumenta, czy posiada wiedze, iż część kosztów może być skredytowania w ciężar kredytu, a część wcale nie musi, a w efekcie czy jest w stanie porównać oferty kredytów konsumenckich i wybrać tę najbardziej korzystną dla siebie. Polski ustawodawca na tle przepisów ogólnych przyjmuje model przeciętnego konsumenta [Ustawa z dnia 23 sierpnia 2007 r. ... $]^{28}$. Zgodnie z art. 2 pkt 8 ustawy o przeciwdziałaniu nieuczciwym praktykom rynkowym przez przeciętnego konsumenta rozumie się konsumenta, który jest dostatecznie dobrze poinformowany, uważny i ostrożny; oceny dokonuje się z uwzględnieniem czynników społecznych, kulturowych, językowych i przynależności danego konsumenta do szczególnej grupy konsumentów, przez którą rozumie się dającą się jednoznacznie zidentyfikować grupę konsumentów, szczególnie podatną na oddziaływanie praktyki rynkowej lub na produkt, którego praktyka rynkowa dotyczy, ze względu na szczególne cechy, takie jak wiek, niepełnosprawność fizyczna lub umysłowa. Zdaniem autorów przeciętny konsument nie posiada jednak na tyle szerokiej wiedzy z dziedziny bankowości, aby samodzielnie podejmować racjonalne decyzje kredytowe, w związku z czym i tak uda się do kredytodawcy bądź pośrednika kredytowego, który przedstawi mu ofertę kredytu konsumenckiego, a także który powinien wyjaśnić wszystkie zagadnienia w tym zakresie, a celem wyboru najkorzystniejszej konsument uda się do kilku z nich i dopiero po tym etapie podejmie ostateczną decyzję.

${ }^{27}$ Ustawodawcy unijni w zakresie stosowanych wewnętrznie aktów prawnych tworzą modele konsumentów na rynkach wewnętrznych uwzględniając odpowiednie kryteria.

${ }^{28}$ Dalej jako ustawa o przeciwdziałaniu nieuczciwym praktykom rynkowym. 


\section{ELIMINACJA NIEUCZCIWYCH PRAKTYK RYNKOWYCH}

Zgodnie z art. 2 lit. b) Dyrektywy 2006/114/WE ${ }^{29}$, ,reklama wprowadzająca w błąd" oznacza każdą reklamę w jakikolwiek sposób, w tym przez swoją firmę, wprowadzającą lub mogącą wprowadzać w błąd osoby, do których jest skierowana lub do których dociera i która, z powodu swej zwodniczej natury, może wpłynąc na ich postępowanie gospodarcze lub która z tych powodów szkodzi lub może szkodzić konkurentowi ${ }^{30}$.

Aby wyeliminować tego typu praktyki z rynku usług finansowych ustawodawca zamieścił w art. 7 ustawy o kredycie konsumenckim wykaz, który był przedmiotem analizy wcześniejszej części niniejszego artykułu i z którego jasno wynika, iż już na etapie reklamy kredytu konsumenckiego, konieczne jest podanie informacji w sposób jednoznaczny, zrozumiały i widoczny.

Słusznie doktryna określa te przepisy jako jeden z elementów systemu ,asysty przedkontraktowej”, przez którą należy rozumieć stworzenie warunków wspomagających proces decyzyjny konsumenta, umożliwiający mu podjęcie optymalnej dla niego decyzji [Czech 2012, Komentarz do Art. 7. Teza 3; Ponadto por. Rogoń 2015: $167 \mathrm{i} \mathrm{n.].}$

Według słownika języka polskiego słowo ,jednoznaczny” oznacza: nie budzący wątpliwości, znaczący to samo [Doroszewski, Słownik..., dostęp: 13.04.2016], w taki więc sposób należy rozumieć treść przekazywanej reklamy w myśl cytowanego powyżej artykułu. Pojęcie „zrozumiała”, słownik języka polskiego thumaczy jako dający się zrozumieć, czyli uświadomić sobie znaczenie wyrazu, wypowiedzi, istnienie relacji między rzeczami, zjawiskami itp. [Doroszewski, Stownik..., dostęp: 13.04.2016] Natomiast słowo „widoczna” to taka, która jest wyraźna, oczywista, dająca się zauważyć [Doroszewski, Słownik..., dostęp: 13.04.2016].

Z powyższej analizy wynika, że pojęcia te częściowo są zbieżne, w związku z czym można wysunąc wnioski, iż informacje wymagane $w$ art. 7 ustawy o kredycie konsumenckim muszą być przedstawione w sposób na tyle jasny, aby nie budziły wątpliwości co do ich treści. Konsument w poparciu o nie powinien samodzielnie móc podjąć wstępną decyzję o korzyściach z wyboru danego produktu. Określając informację jako widoczną należy mieć na uwadze zwłaszcza czas ich prezentacji, rozmiar czcionki, faktyczną możliwość zapoznania się z jej treścią, nośnik informacji przez jaki jest przekazywana. Nie można mówić o widoczności jeśli informacja jest częściowo ukryta np. poprzez celowe użycie

${ }^{29}$ Dyrektywa 2006/114/WE z dnia 12 grudnia 2006 r. dotycząca reklamy wprowadzającej w błąd i reklamy porównawczej (Dz.U. UE L z 2006 r. Nr 376, str. 21, wersja ujednolicona).

${ }^{30} \mathrm{O}$ wprowadzania konsumenta w błąd w wyniku przekazu informacji w reklamie zob. także: Rutkowska-Tomaszewska [2014c: 69-73]. 
tła powodujące rozmywanie się lub utrudnione odczytanie tekstu. Jak wskazuje doktryna nie powinno się również stosować elementów graficznych, które mogłyby odwracać uwagę konsumenta od istotnych informacji, w szczególności w telewizyjnych spotach reklamowych [Ofiarski 2012, Komentarz do Art. 7. Teza 3]. W ujęciu tego problemu należy mieć na uwadze, iż innymi zasadami powinniśmy się kreować w przypadku reklamy telewizyjnej, radiowej czy też prasowej.

Na nieprawidłowości w tym zakresie zwrócił uwagę Prezes UOKiK, który zauważył, iż informacje przekazywane $\mathrm{w}$ spotach telewizyjnych wybranych banków, były przedstawione w sposób uniemożliwiający ich odczytanie z uwagi na wielkość czcionki oraz krótki czas ich prezentacji. Urząd Ochrony Konkurencji i Konsumentów stwierdził, że reklamy telewizyjne pięciu instytucji finansowych Alior Bank (kampania „Gwarancja najniższej raty”), Bank BGŻ BNP Paribas (kampania „Orzech odsetkowy”), Euro Bank (kampania „Warto sprawdzić jakość i cenę. Kredyt gotówkowy z atrakcyjnym oprocentowaniem już od 5,7 proc.”), Credit Agricole Bank Polska (kampania „Kredyt prostoliczony za 10 zł”) Provident Polska (kampania „Spróbuj i zostań”) nie spełniały wymogów określonych w ustawie o kredycie konsumenckim [Reklamy kredytów..., dostęp: 13.04.2016]. Zakwestionowano 31 spotów, które były emitowane w okresie od marca do września 2014 r. Zastrzeżenia Urzędu dotyczyły sposobu prezentowania kosztów kredytu. Ważne dla konsumenta informacje o oprocentowaniu, całkowitej kwocie do zapłaty, czy RRSO były napisane drobną czcionką i pokazywane zbyt krótko aby możliwe było ich odczytanie. Przykładowo w 30-sekundowym filmie tekst zawierający wymagane przepisami prawa informacje był wyświetlany jedynie przez 2 sekundy [Reklamy kredytów..., dostęp: 13.04.2016]. Nie trudno uznać, że w tak krótkim czasie nikt nie jest w stanie zapoznać się choćby z częścią informacji, a już całkowicie niemożliwe jest uznanie jej za jasną i zrozumiałą.

Ustawodawca jako potencjalny skutek nowych przepisów zawartych w art. 7 ustawy o kredycie konsumenckim regulujących zakres reklamy, przewidywał wzmożoną konkurencję kredytodawców, co niewątpliwie wpłynie na poprawę sytuacji konsumentów [Uzasadnienie projektu ustawy o kredycie konsumenckim..., dostęp: 13.04.2016]. Z analizy odpowiedzi, na interwencję Prezesa UOKiK, przesłanych przez banki wynika, iż ich zdaniem okolicznościami, które powinny decydować o tym, iż ich przekazy reklamowe nie naruszały zbiorowych interesów konsumentów jest fakt, iż:

- brak jest przepisów w zakresie wymogów czytelności spotów reklamowych, a forma prezentowania informacji nie odbiega od powszechnej praktyki rynkowej w tym zakresie, 
- specyfika przekazu reklamowego narzuca pewne ograniczenia w zakresie prezentowanych treści, zarówno pod względem ilości przekazywanych informacji jak i formy przekazywania tych informacji,

- niektóre z banków zwiększyły ekspozycję noty prawnej do połowy czasu trwania spotu reklamowego,

- celem reklamy były jedynie przypomnienie konsumentowi o ofercie banku,

- informacje wyświetlane podczas emisji kwestionowanych spotów były bez ograniczeń dostępne w oddziałach banku oraz na stronie internetowej [Decyzje Prezesa UOKiK Nr DDK 3/2016; DDK 4/2016; DDK 5/2016; DDK 6/2016; DDK 7/2016 z 9 marca 2016 r., www.uokik.gov.pl].

Powyższe argumenty banków pokazują, iż zamierzony przez ustawodawcę skutek nie został osiągnięty, gdyż instytucje oferujące usługi kredytowe opracowały wspólną praktykę, która pomimo naruszania praw konsumentów była powszechnie stosowana. Był to skutek odmienny od oczekiwanego.

Prezes UOKiK zwrócił uwagę, że przekaz zawarty w ocenianych reklamach telewizyjnych banków nie był widoczny dla konsumenta. Jego zdaniem na kwestię czytelności miały wpływ: krótkie czasy prezentacji wymaganych informacji (które średnio trwały 4 sekundy, a maksymalnie 9 sekund w przypadku jednego z banków), duża ilość przekazywanych informacji, a także mała czcionka za pomocą której były prezentowane informacje. Nie bez znaczenia pozostawał fakt, że banki używały haseł reklamowych, które zajmowały znaczną część ekranu i odciągały uwagę widza od wymaganych informacji, o których mowa $\mathrm{w}$ art. 7 ustawy o kredycie konsumenckim [Decyzje Prezesa UOKiK Nr DDK 3/2016; DDK 4/2016; DDK 5/2016; DDK 6/2016; DDK 7/2016 z 9 marca 2016 r., www.uokik.gov.pl].

Odpowiadając na zarzuty banków Prezes UOKiK stwierdził [Decyzje Prezesa UOKiK Nr DDK 3/2016; DDK 4/2016; DDK 5/2016; DDK 6/2016; DDK 7/2016 z 9 marca 2016 r., www.uokik.gov.pl], iż przepisy ustawy o kredycie konsumenckim wskazują, że reklama powinna być jednoznaczna, zrozumiała i widoczna. To na przedsiębiorcy spoczywa obowiązek doboru środków przekazu w taki sposób, aby obowiązek ustawowy wypełnić. Tłumaczenie, iż nie ma szczegółowych regulacji dotyczących sposobu prezentacji informacji w spotach reklamowych jest więc bezzasadne. Ponadto Prezes UOKiK stwierdził również, iż wybierając medium służące do prezentacji reklamy, banki powinny mieć świadomość, że to na nich spoczywa obowiązek i odpowiedzialność, by dostosować swoje komunikaty, zawierające wymagane przepisami prawa informacje, do możliwości danego medium. Dodatkowo w trakcie postępowania Prezes UOKiK dokonał tzw. testu przeciętnego konsumenta, który wykazał, iż abstrahując od zrozumienia komunikatów przekazywanych konsumentom, nawet ostrożny i uważny konsument miałby problem z odczytaniem komunikatów stosowanych przez banki. Tym samym zwrócił uwagę, iż w przypadku emisji 
przedmiotowych reklam bankowych należy pominąć całkowicie rozważania na temat zrozumienia przeciętnego konsumenta przekazywanych treści, gdyż w tak ograniczonym czasie prezentacji brak jest możliwości choćby fizycznego odczytania komunikatu. Ponadto co również jest znamienne w omawianym zakresie, Prezes UOKiK uznał, iż reklama, które naraża potencjalnego kredytobiorcę na mitręgę czasu w celu zdobycia informacji, które powinny znaleźć się już w reklamie nie wypełnia celów dyrektywy 2008/48/WE, a także ustawy o kredycie konsumenckim. Obowiązek nałożony przez ustawę o kredycie konsumenckim dotyczy każdej reklamy, która nie może być uzupełniana innymi źródłami. Mając wszystkie powyższe rozważania na uwadze Prezes UOKiK uznał w swoich decyzjach [Decyzje Prezesa UOKiK Nr DDK 3/2016; DDK 4/2016; DDK 5/2016; DDK 6/2016; DDK 7/2016 z 9 marca 2016 r., www.uokik.gov.pl], iż postępowanie banków narusza zbiorowe interesy konsumentów ${ }^{31}$.

Po przeprowadzonym postępowaniu w sprawie praktyk naruszających zbiorowe interesy konsumentów Prezes UOKiK nałożył na banki obowiązek publikacji w Programie Pierwszym Telewizji Polskiej oświadczenia, iż działaniem banku zostały naruszone zbiorowe interesy konsumentów. Informacja taka miała się również znaleźć na stronach internetowych poszczególnych banków.

Już w trakcie postępowania Prezesa UOKiK wybrane Banki zobowiązały się do następujących zmian:

- Alior Bank S.A. do wyświetlania noty prawnej w czcionce stanowiącej co najmniej $40 \%$ średniej wielkości napisów marketingowych stosowanych w reklamie, wydłużając czas jej ekspozycji w reklamie 30-sekundowej do 27 sekund, a w reklamie 15-sekundowej do 13 sekund [Decyzja Prezesa UOKiK nr DDK 3/2016],

- Credit Agricole Bank Polska S.A. do wyświetlania noty prawnej w zwiększonym formacie czcionki, wydłużając czas jej wyświetlenia dla 30-sekundowej reklamy do minimum 13 sekund, a dla reklamy 15 -sekundowej do minimum 15 sekund [Decyzja Prezesa UOKiK nr DDK 4/2016],

- Bank BGŻ BNP Paribas S.A. do wyświetlania noty prawnej dla 30-sekundowej reklamy do minimum 21 sekund, a dla reklamy 15-sekundowej do minimum 15 sekund [Decyzja Prezesa UOKiK nr DDK 5/2016],

- Euro Bank S.A. do wyświetlania noty prawnej w czcionce zwiększonej o $20 \%$ oraz dokonanie podziału tekstu na kolumny oraz podpunkty, a jednocześnie wyeliminowanie spotów reklamowych 15-sekundowych, a w spotach 30 sekundowych wydłużenie czasu ekspozycji noty prawnej z 27 sekund do 30 sekund wraz ze zmianą propozrcji emisji poszczególnych fragmentów, tak aby informacja o rzeczywistej rocznej stopie oprocentowania była wyświetlana

${ }^{31} \mathrm{~W}$ zakresie pojęcia i przesłanek uznania praktyki za naruszające zbiorowe interesy konsumentów zob. Rutkowska-Tomaszewska [2014c]. 
najdłużej (zmiana z 10 sekund do 13 sekund) [Decyzja Prezesa UOKiK nr DDK 6/2016].

W ocenie Autorów nie zmienia to faktu, że nawet 30 sekundowa informacja wymagająca specjalistycznej wiedzy, nie pozwala na zapoznanie się i zrozumienie przekazywanych treści. Wymagana ilość informacji jakie muszą zostać przekazana konsumentowi w reklamie nie może zostać przyswojona, i mało realne wydaje się, że możliwe jest nadążenie za komunikatem prasowym w tym samym momencie kiedy na ekranie wyświetlane są informacje marketingowe. Warto się więc zastanowić czy zasadne jest wymaganie od kredytodawcy przedkontraktowego obowiązku informacyjnego skoro nie jest to jedyny moment kiedy konsument ma możliwość zapoznania się z ofertą banku.

\section{PODSUMOWANIE}

Zdaniem autorów po analizie problemu nasuwają się następujące wnioski:

1. Na usługi finansowe nałożony jest wyższy wymóg informacyjny, gdyż wiąże się to zarówno z wysokim ryzykiem, niską świadomością i poziomem wiedzy konsumenta w danym zakresie jak i specyficzną rolą kredytów na rynku usług konsumenckich;

2. Ustawodawca dzięki zastosowanym przepisom pozwala konsumentowi na świadome i realne porównanie usług kredytowych z różnych instytucji, co niewątpliwie wpływa na zmniejszenie ryzyka, przy założeniu wysokiej świadomości prawnej i ekonomicznej konsumentów;

3. Zawarcie wymaganych w ustawie informacji nie wpływa istotnie na skrócenie procesu decyzyjnego konsumenta, który rozważając możliwość zawarcia umowy o kredyt konsumencki zmuszony jest udać się bezpośrednio do kredytodawcy lub pośrednika kredytowego w celu zasięgnięcia dokładnej informacji i analizy ofert;

4. Pozytywnie należy ocenić działania Prezesa UOKiK, w wyniku których motywuje się banki do podjęcia działań mających na celu polepszenie sytuacji konsumenta na rynku usług finansowych;

5. Wydłużenie czasu prezentowania informacji prawnej $\mathrm{w}$ momencie reklamy nie ma zbyt istotnego wpływu na faktyczne zapoznanie się z koniecznymi informacjami, a tym bardziej na zrozumienie ich;

6. Działania Prezesa UOKiK nie wiążą się z konsekwencjami, które mogłyby zostać uznane za dotkliwe, a tym samym mieć wpływ na eliminację takich działań w przyszłości.

Analiza celów regulacji normatywnej minimalnego zakresu informacji zawartych w reklamach usług finansowych mimo ich formalnego umieszczenia, nie spełnia zamierzonego przez ustawodawcę skutku w postaci zawarcia umo- 
wy, którą konsument chciał zawrzeć, którą rozumie i na którą rzeczywiście się zgadza. Przekazywanie znacznej ilości informacji o charakterze czysto technicznym jak np. informacja o RRSO jest zbędne, gdyż przeciętny adresat tego typu reklam, ma niską świadomość znaczenia owego wskaźnika ekonomicznego, pomimo faktu, iż dzięki jego wykorzystaniu konsument jest w stanie porównać alternatywne oferty tego samego sektora usług finansowych.

Autorzy nie kwestionują w żadnym wypadku prawa konsumenta do informacji jako podstawowego elementu w obrocie konsumenckim. Niewłaściwy jest jednak moment, sposób i ilość informacji jakie należy przekazać konsumentowi w reklamie produktów finansowych. O ile, bowiem w ulotce papierowej, z która można się zapoznawać wielokrotnie i przez nieograniczony czas można zawrzeć więcej danych, to równoczesne zapoznawanie się $\mathrm{z}$ informacją prawną i skupienie na informacji marketingowej, w przypadku spotów reklamowych, jest praktycznie niemożliwe. W tej sytuacji należałoby poważnie zastanowić się nad propozycją wskazywaną przez część doktryny dotyczącą ustanowienia zakazu reklamy usług bankowych [Góral 2012: 403], albo co najmniej zakazu reklamy w formie spotów reklamowych.

Dla odpowiedniej ochrony interesów konsumentów, zamiast mnożyć dodatkowe regulacje prawne, wystarczające byłoby, aby podmiot finansowy działał uczciwie i rozważnie, z poszanowaniem interesu klientów i dobra rynku finansowego [Kanon Dobrych Praktyk, dostęp: 20.04.2016; zob. także Góral 2012: 397]. Aby zapobiec inflacji przepisów prawnych w omawianym zakresie i wystarczający sposób ochronić interesy konsumentów należałoby stosować się do ogólnych reguł wyrażonych w art. 3 ustawy o zwalczaniu nieuczciwej konkurencji [Ustawa $\mathrm{z}$ dnia 16 kwietnia 1993 r. ...] ${ }^{32}$. Brak stosowania tego typu zaleceń widoczny jest w analizowanych odpowiedziach banków, które usprawiedliwiały swoje praktyki brakiem dokładnych regulacji i wymogów w tym zakresie, tak jak w przypadku reklam produktów farmaceutycznych, które wymuszają określone zachowania.

Instytucje finansowe muszą więc uwzględniać przepisy ogólne, które chronią prawa konsumenta $\mathrm{i}$ na podstawie ich wykładni dostosowywać prezentacje i oferty produktów kredytowych, a nie wykorzystywać brak szczegółowych regulacji w tym zakresie.

${ }^{32}$ Zgodnie z art. 3 ust. 1 i 2 Czynem nieuczciwej konkurencji jest działanie sprzeczne z prawem lub dobrymi obyczajami, jeżeli zagraża lub narusza interes innego przedsiębiorcy lub klienta, w szczególności czynem takim jest: wprowadzające w błąd oznaczenie przedsiębiorstwa, fałszywe lub oszukańcze oznaczenie pochodzenia geograficznego towarów albo usług, wprowadzające w błąd oznaczenie towarów lub usług, naruszenie tajemnicy przedsiębiorstwa, nakłanianie do rozwiązania lub niewykonania umowy, naśladownictwo produktów, pomawianie lub nieuczciwe zachwalanie, utrudnianie dostępu do rynku, przekupstwo osoby pełniącej funkcję publiczną, a także nieuczciwa lub zakazana reklama, organizowanie systemu sprzedaży lawinowej oraz prowadzenie lub organizowanie działalności w systemie konsorcyjnym. 


\section{BIBLIOGRAFIA}

\section{Źródła prawa międzynarodowego}

Dyrektywa 2006/114/WE z dnia 12 grudnia 2006 r. dotycząca reklamy wprowadzającej w błąd i reklamy porównawczej, Dz.U. UE L 2006 r., Nr 376, str. 21, wersja ujednolicona.

Dyrektywa Parlamentu Europejskiego i Rady 2008/48/WE z dnia 23 kwietnia 2008 r. w sprawie umów o kredyt konsumencki oraz uchylająca dyrektywę Rady 87/102/EWG, Dz.U. UE. L. 2008 r., Nr 133, str. 66 z późn. zm.

Dyrektywa Parlamentu Europejskiego i Rady 2014/17/UE z dnia 04 lutego 2014 r. w sprawie konsumenckim umów o kredyt związanych z nieruchomościami mieszkalnymi i zmieniającej dyrektywy 2008/48/WE i 2013/36/UE, Dz.U. L 60 z 28.2.2014 r., s. 34-85.

\section{Źródła prawa krajowego}

Konstytucja Rzeczypospolitej Polskiej z dnia 02 kwietnia 1997 r., Dz.U., nr 78, poz. 483.

Obwieszczenie Ministra Sprawiedliwości z dnia 07 stycznia 2016 r. w sprawie wysokości odsetek ustawowych, M.P. 2016, poz. 46.

Ustawa z dnia 09 października 2015 r. o zmianie ustawy o terminach zapłaty w transakcjach handlowych, ustawy - Kodeks cywilny oraz niektórych innych ustaw, Dz.U. 2015, poz. 1830.

Ustawa z dnia 12 maja 2011 r. o kredycie konsumenckim, tj. Dz.U. 2016, poz. 1528.

Ustawa z dnia 16 kwietnia 1993 r. o zwalczaniu nieuczciwej konkurencji, t.j. Dz.U. 2003, nr 153, poz. 1503 z późn. zm.

Ustawa z dnia 23 kwietnia 1964 r. - Kodeks cywilny, tj. Dz.U. 2017, poz. 459.

Ustawa z dnia 23 marca 2017 r. o kredycie hipotecznym oraz o nadzorze nad pośrednikami kredytu hipotecznego i agentami, Dz.U. 2017, poz. 819.

Ustawa z dnia 23 sierpnia 2007 r. o przeciwdziałaniu nieuczciwym praktykom rynkowym, t.j. Dz.U. 2016, poz. 3 z późn. zm.

Ustawa z dnia 29 grudnia 1992 r. o radiofonii i telewizji, t.j. Dz.U. 2016, poz. 639 z późn. zm.

Ustawa z dnia 30 maja 2014 r. o prawach konsumenta, t.j. Dz.U. 2017, poz. 683.

\section{Orzecznictwo krajowe}

Wyrok Sądu Najwyższego z dnia 20 czerwca 2006 r. Sygn. III SK 7/06 - OSNP 2007 nr 13-14 poz. 207, LEX Omega 2015.

Wyrok Trybunału Konstytucyjnego z dnia 21 kwietnia 2004 r. Sygn. K 33/03, OTK-A 2004, nr 4, poz. 31.

\section{Literatura}

Chruściak M., Kopeć A., Kłoda M., Kott G., Ostrowski T., Szakun M., 2012, Ustawa o kredycie konsumenckim. Rekomendacje interpretacyjne podstawowych regulacji. Komentarz, Legalis, Warszawa.

Czech T., 2012, Kredyt konsumencki. Komentarz, Wydawnictwo Prawnicze LexisNexis.

Doroszewski W. (red.), Słownik języka polskiego, www.sjp.pwn.pl

Góral L., 2012, Reklama a informacja o uslugach bankowych, [w:] M. Namysłowska (red.), Reklama. Aspekty prawne, wyd. 1, Wolters Kluwer Polska S.A.

Kopeć-Kowalczyk M., 2014, Reklama kredytu konsumenckiego w świetle ustawy o kredycie konsumenckim, „Studia Iuridica”, nr 58.

Ofiarski Z., 2015, Ustawa o kredycie konsumenckim. Komentarz, LEX.

Reklamy kredytów konsumenckich - decyzje UOKiK, https://uokik.gov.pl/aktualno-sci.php?news _id $=12283$. 
Rogoń D., 2015, Kredyt hipoteczny w „pakiecie” z ustuga dodatkowa $w$ świetle dyrektywy hipotecznej, [w:] M. Kućka, K. Pałka (red.), Nie tylko hipoteka... Zeszyt jubileuszowy dedykowany profesorowi Jerzemu Pisulińskiemu, Warszawa.

Rutkowska-Tomaszewska E., 2011, Nieuczciwe praktyki na rynku bankowych ustug konsumenckich, wyd. 1, Wolters Kluwer Polska S.A., [za:] Międzynarodowy Kodeks Etyczny Reklamy Izba Handlowa w Paryżu 1939 r., LexOmega 2015.

Rutkowska-Tomaszewska E., 2014a, Bankowość konsumencka, [w:] W. Góralczyk (red.), Problemy współczesnej bankowości, wyd. 1, Wolters Kluwer Polska S.A., (LEX).

Rutkowska-Tomaszewska E., 2014b, Obowiązi informacyjne $w$ ustawie o kredycie konsumenckim, [w:] W. Góralczyk (red.), Problemy wspótczesnej bankowości, wyd. 1, Wolters Kluwer Polska S.A., (LEX).

Rutkowska-Tomaszewska E., 2014c, Praktyki naruszajace zbiorowe interesy konsumentów na rynku ustug finansowych ze szczególnym uwzględnieniem rynku usług bankowych na przykładzie wybranych najnowszych decyzji Prezesa UOKiK, Internetowy Kwartalnik Antymonopolowy i Regulacyjny, nr 5(3) - www.ikar.wz.uw.edu.pl.

Tereszkiewicz P., 2014, Obowiazki informacyjne w umowach o ustugi finansowe, wyd. 1, Wolters Kluwer Polska S.A.

\section{Inne}

Decyzja częściowa Prezesa UOKiK Delegatura w Bydgoszczy nr RBG - 10/2014 z 22 maja 2014 r.

Decyzja Prezesa UOKiK Nr DDK 3/2016 z 09 marca 2016 r.

Decyzja Prezesa UOKiK Nr DDK 4/2016 z 09 marca 2016 r.

Decyzja Prezesa UOKiK Nr DDK 5/2016 z 09 marca 2016 r.

Decyzja Prezesa UOKiK Nr DDK 6/2016 z 09 marca 2016 r.

Decyzja Prezesa UOKiK Nr DDK 7/2016 z 09 marca 2016 r.

European Commission, Commission staff working document Guidelines on the application of directive 2008/48/WE (consumer credit directive) in relation to costs and the annual percentage rate of charge, $\mathrm{SWD}(2012) 128$ final, Bruksela 08.05.2012.

Kanon Dobrych Praktyk Rynku Finansowego, www.rf.gov.pl.

Pismo Komisji Nadzoru Finansowego z 13.04.2012 r., nr DOK/WPR/0735/5/1/12/BK.

Pismo Urzędu Ochrony Konkurencji i Konsumentów z 20.02.2012 r., nr DDK-076-118/11/BK.

Raport kwartalny z marca 2017 r. Biura Informacji Kredytowej Kredyt Trendy opracowany przez Departament Business Intelligence w Biurze Informacji Kredytowej S.A.

Uzasadnienie projektu ustawy o kredycie konsumenckim z dnia 15 listopada 2010 r., Druk Sejmu VI kadencji, Nr 3596, www.sejm.gov.pl.

Uzasadnienie rządowego projektu ustawy o kredycie hipotecznym oraz o nadzorze nad pośrednikami kredytu hipotecznego i agentami, Druk Sejmu VIII kadencji, $\mathrm{Nr}$ 1210, www.sejm.gov.pl. 


\title{
ABUSE OF CONSUMER RIGHTS IN FINANCIAL SERVICE ADVERTISING
}

\begin{abstract}
This publication pertains to disclosure requirements which legislator imposes on creditors and credit intermediaries already at the stage of advertising consumer credits. These obligations, resulting from Consumer Credit Act, are not always respected by financial institution providing this type of service. Such conclusions can be drawn based primarily on last analysis of decisions made by the President of UOKiK, who pointed out numerous irregularities in this scope. In this note disclosure requirements in the field of offering credit services, included in the Consumer Credit Act, will be discussed.
\end{abstract}

Keywords: consumer, consumer credit, advertising of financial services, Office of Competition and Consumer Protection, disclosure requirements.

Przyjęto/Accepted: 04.05.2017

Opublikowano/Published: 30.06.2017 